\title{
DEMOCRACY VERSUS THE NATIONAL SECURITY STATE
}

\author{
Marcus G. Raskin* \\ INTRODUCTION
}

It is not possible to understand the national security state and the reasons which give rise to the need for dismantling it without mentioning the profound and wrenching events of the last fifty years. The national security state emerges from war, from fear of revolution and change, from the economic instability of capitalism, and from nuclear weapons and military technology. ${ }^{1}$ It has been the actualizing mechanism of ruling elites to implement their imperial schemes and misplaced ideals. ${ }^{2}$ In practical terms its emergence is linked to the rise of a bureaucracy that administered things and people in interchangeable fashion without concern for ends or assumptions. ${ }^{3}$ This state formation matured during a period in which the office of the President became supremely powerful as a broker and legitimating instrument of national security activity. ${ }^{4}$

This paper argues in somewhat tendentious and breathless form that the state system which has emerged in the United States is a constitutional deformation which menaces the freedom and well being of its citizenry, and which poses a danger to world civilization. What is hanging in the balance in the last twenty-five years of this century is whether the people, scholars, lawyers and judges, and members of the government, can so organize their understanding and their political actions as to avert fascism or Bonapartism, a debilitating arms race that could end in the kind of horror from which there will be no redemption, and a decaying economic system which impoverishes Americans as well as people elsewhere. ${ }^{5}$ It is this cluster of questions which public schol-

\footnotetext{
* Co-Director, Institute for Policy Studies, Washington, D.C.

1. See gemerally R. Barnet. Intervention and Revolution, The United States in the Third World (1968); L.B. Johnson. The Vantage Point (1971); J. O'Connor, The Fiscal Crisis of The State (1973); M. Raskin, Being and Doing 47-76 (1971): R. Stavins, R. Barnet, \& M. Raskin, Washington Plans an Aggressive War 199-252 (1971): Borosage, The Making of the National Security State, in The Pentagon Watchers: Student Report on the National Security State 3-64 (L. Rodberg \& D. Shearer eds. 1970); Raskin. The Kennedy Hawks Assume Power From the Eisenhozer Vultures, in The Pentagon Watchers: Student Report on the National SeCurity State $65-98$ (L. Rodberg \& D. Shearer eds, 1970).

2. C. Mills, 2 The Power Elite 274-78 (1956).

3. Raskin, Book Review. I N.Y. Rev. Books, Nov. 14, 1963, at 6.

4. G. Novack. Democracy and Revolution 152 (1971); M. Raskin, Notes on the Old SYSTEM $7-35$ (1974).

5. M. Raskin, The Common Good (forthcoming 1978, Simon \& Schuster).
} 
ars and statesmen need to address and act upon during the remainder of this century. It is the assumption of this paper that there is a contradictory and healthy cultural movement in this direction which seeks democratization and participation in questions of politics and economics. ${ }^{6}$ Such participation is sought, not as an end in itself-although that would be a good end-but because more prudent and even ethical judgments would be made through popular participation and discussion. ${ }^{7}$

The National Security State as the Ballast for AMERICAN SUPREMaCy IN THE WORLD

In 1945 the United States emerged from the second world war as the most powerful nation in the world. Its allies were dependent on the United States for the kind of economic aid that was needed to restore the pre-war social and economic structures of Europe, ${ }^{8}$ and the vanquished were, of course, totally dependent on the largesse of the United States." The colonial areas of the world looked to the United States for aid in their national independence struggles against France, Great Britain, and the Netherlands. ${ }^{10}$ American scientists, with help from European scientists, scaled the heights to become "the destroyer of worlds," as J. Robert Oppenheimer put it, with the atomic bomb. ${ }^{11}$ Roosevelt and Churchill had decided in 1944 that the weapon was to be kept secret from the Soviet Union to assure immediate and complete supremacy at the close of the war. ${ }^{12}$ It was no wonder that American leaders felt a certain omnipotence and arrogance during the immediate postwar period. American leadership had gained enormously in prestige and material power from the second world war, ${ }^{13}$ and Americans were honored and respected by communists and colonized people alike. Indeed, during the second world war the American Communist Party dissolved itself to become an "as-

6. See generally M. Freeman, The Politics of Women's Liberation: A Case Study of Emerging Social Movements and lts Relation to the Policy Process 170-244 (1975); P. Goodman, People or Personnel: Decentralizing and the Mixed System 28-49, 147-73 (1963); L. Mumford, The Myth of the Machine: Technics and Human development (1966); J. Phelan \& R. Pozen, The Company State: Ralph Nader's Study Group Report on DuPont in Delaware (1973); M. RaSkin, supra note 5.

7. H. Arendt, On Revolution 252-60 (1963).

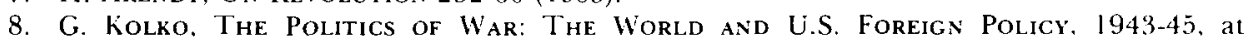
$618-26$ (1968).

9. J. Jones, The Fifteen Weeks (February 21 to June 5, 1947), at 28 (1955).

10. 2 D. Fleming, The Cold War and Its Origins, 1917-1960, at 661-706 (1961); G. Kahin, Nationalism and Revolution in Indonesia 344-45, 417-23 (1952); The Vietnam Reader (M. Raskin \& B. Fall eds. 1965); The Price of Vision, The Diary of Henry A. Wallace, 1942-1946, at 85-6 (J. Blum ed. 1973).

11. P. Stern, The Oppenheimer Case, Security on Trial 81 (1969).

12. M. Sherwin, A World Destroved: The Atomic Bomb and the Grand Alelance 209 (1975).

13. E. Janeway, The Economics of Crisis: War, Politics and the Dollar 28 (1968). 
sociation" because, according to Earl Browder, the American capitalists were different from the European brand. ${ }^{14}$ And revolutionaries like Ho Chi Minh modeled their Declaration of Independence after the American eighteenth century document. ${ }^{15}$

Yet at the close of the second world war there remained profound doubts concerning the viability of the capitalist system, doubts which had their roots in the depression, doubts which the accomplishments of the New Deal had not entirely eradicated. It was true that even big businessmen had begrudgingly accepted the New Deal as a political success. ${ }^{16}$ After all, it had succeeded in papering over class and racial conflict by way of the political coalitions of the Democratic Party aided by the FDR charisma. For the first time in American history there was a strong belief among American leaders that class conflict could be muted, managed, and perhaps transcended. But this assumption was a daring one and one which was not wholly believed. On the eve of the second world war the United States had not recovered from its economic depression. The various measures which had been tried by Franklin Roosevelt and his advisors, such as creating public works programs, curbing the excesses of the stock market, and guaranteeing farm loans to farmers, proved insufficient to meet the challenge of an economy which was called on to respond to "pump priming" and the contradictory programs of the New Deal. ${ }^{17}$ In 1938-1939 the unemployment rate of the United States was 18 percent and there did not seem to be a means of rationalizing the needs of the people with the short and long term interests of capitalism. From 1931 to 1940 the jobless rate never fell below 14 percent-and in four years it averaged more than 20 percent. ${ }^{18}$ It was generally assumed by government economists that after pent-up demand had been met, the United States in a postwar situation would again be faced with serious unemployment. It should be noted that in 1941, the last year of a quasi-mobilization economy, unemployment hovered at 10 percent. $^{19}$

It is no wonder, then, that at the close of the second world war there remained profound doubt about the viability of the capitalist system. As A.A. Berle has said, "[I]n terms of power, without regard to asset positions, not only do 500 corporations control two-thirds of the non-farm economy but within each of that 500 a still smaller group has the ultimate decision making

\footnotetext{
14. I. Howe \& L. Coser, The American Communist Party 426 (2d ed. 1962).

15. B. Fall, The Viet Minh Regime: Governient and Administration in the Democratic Rfpublic of Viet Nam 5 (rev. \& enl. ed. 1956).

16. B. CatTon, The War Lords of WashiNgton 8, 24 (1948).

17. G. Perrett, Days of Sadness, Years of Triumph, The American People, 1939-1945, at 173-85 (1973); A. Schlesinger, Jr., The Age of Roosevelt: The Coming of the New Deal (1958).

18. H. Ginsberg, Unemployment, Subemployment, and Public Policy 3 (1975).

19. Id. at 6 .
} 
power. This is, I think, the highest concentration of economic power in recorded history." 20 There had been an active anti-business ideology during the depression. Business concentration and the growing cynicism about consumer "goods" has recently caused the reemergence of this old hostility against the big corporations, which has been analyzed by Irving Kristol: ${ }^{21}$

The old hostility is based on what we familiarly call 'populism.' This is a sentiment basic to any democracy-indispensable to its establishment but also, ironically, inimical to its survival. Populism is the constant fear and suspicion that power and/or authority, whether in government or out, is being used to frustrate 'the will of the people.' It is a spirit that intimidates authority and provides the popular energy to curb and resist it.

Kristol recognizes that populism easily degenerates into paranoia in the minds of most Americans. "[M]ost Americans are now quick to believe that big business' conspires secretly but most effectively to manipulate the economic and political system-an enterprise which, in prosaic fact, corporate executives are too distracted and too unimaginative even to contemplate." ${ }^{22}$

While the anti-business ideology of the depression did not reach the proportion of successful demands for systemic change, it was strong enough that at the end of the second world war it acted as a spur to business leaders to find ways of stabilizing capitalism. It was only a scant few years since the bread lines of the depression. Broken-spirited people had been demoralized by the contradiction which the corporate economic system proposed to the kind of individualism which asserted that each person "could make it on his own." This corporate order (never contemplated by the Constitution) had accumulated masses of capital and equipment to control the productive processes of the society so that the means of livelihood were controlled by an oligarchic few, out of the reach of the worker or farmer. Strike turbulence in all major industries in the 1945-1948 period fueled the corporate governmental need for careful handling of the labor situation. ${ }^{23}$ During the war most unions had accepted a no-strike pledge in exchange for certain minor management prerogatives in the plants. ${ }^{24}$ These arrangements were dissolved at the end of the war as management sought to take back all control over life in the factory. Truman threatened to take over the coal mines and railroads, while draftees in the armed forces rioted to return to civilian life. ${ }^{2.5}$

Thus American national life seemed to be returning to economic and social chaos in the immediate postwar period. On the international scene, the

\footnotetext{
20. A. Berle, Economic Power and the Free Society 14 (1957).

21. Kristol, On Corporate Capitalism in America, 41 Pub. INTEREST 126-27 (Fall 1975).

22. Id at 128.

23. A. Goldberg, AFL-CiO: Labor United 44 (1956); J. Mattes \& J. Higgins. Them \& Us $38-172(1974)$.

24. P. Taft, Organized Labor IN AMerican History 546 (1964).

25. J. BLum, supra note 10 , at 266 .
} 
British informed the United States that Greece and Turkey were now American imperial responsibilities. In March 1947 the United States intervened in both places and established its sphere of influence. ${ }^{26}$ Such "opportunities" and problems gave rise to a different kind of governing structure; one which would enable the United States to exercise world hegemony while ensuring internal social and economic stability. The American leadership attempted to reorganize the government. It would appear to be democratic and it would appear to steer an economic and political course between socialism and fascism, the two major ideologies of the twentieth century. We have referred to this system as the national security state. It was guided by a small group of men who, through ties of interest and social class, reacted to the world in essentially the same way.

A center piece of the governmental reorganization was the adoption of the National Security Act of 1947 and the creation of a National Security Council which was to integrate "domestic, foreign and military policies relating to the national security so as to enable the military services and the other departments and agencies of the Government to cooperate more effectively in matters involving national security." 27 Three major structural purposes were intended to be served by this legislation. One was the development and creation of an intelligence capability known as the Central Intelligence Agency (CIA). It legitimated secrecy and intelligence as a necessary form of government. Another was the reorganization of the independent armed services under the Secretary of Defense, with a Joint Chiefs of Staff system. This system grew out of the need to "rationalize global responsibilities" in a common planning system. The third was to ensure that the domestic economy would make available resources and material for defense and national security purposes. It should be noted that while a "National Security Council" was created, no definition of national security was formulated in the Act or in ensuing acts which ostensibly dealt with national security. The concept remained one which was to be defined through positive action and, tautologically, by those who had exercised power in the military, financial, and bureaucratic elites. The National Security Act allowed the various agencies to broaden and interpret their own mandate. The consequences of vesting the national security apparatus with such unchecked discretion were soon apparent. According to Arthur Macy Cox, a former member of the CIA, the CIA entered into covert collection and covert operations from its incipient stages, hiring a former Nazi general, Gerhard Gehlen, to develop an intelligence network on the Soviets. ${ }^{28}$

26. R. Barnet, supra note 1, at 97-128; F. Dulles, America's Rise to World Power, 1898-1954, at 231-32 (1953); Paterson, The Quesi for Peace and Prosperity, in Politics and Policies of the Truman Administration 91-2 (B. Bernstein ed. 1970).

27. The National Security Act of $1947 \S 1016,50$ U.S.C. $\$ 402$ (a) (1970).

28. A. Cox, The Myths of the National Security State 93 (1975). 
This act had immediate international significance. "There can be little doubt that the Soviets, fearing the Germans more than any other people, were greatly influenced in their assessment of U.S. intentions by the fact that the United States selected Gehlen for this role." ${ }^{29}$ Needless to say, governmental reorganizations have their ideological import.

\section{A. Cooling Labor Unrest}

Reinhold Niebuhr, an intellectually influential exponent of the national security state and the cold war, argued that within the United States a partnership had been achieved between capital and labor, and this partnership could be maintained if organized labor were given a role in the national security system. ${ }^{30}$ Such was the impetus behind the passage of the Employment Act of $1946,{ }^{31}$ a piece of legislation which was viewed by its supporters as an instrument for taming capitalism and giving the workers a stake in its maintenance. The incongruities of the Act are apparent. Aimed at creating conditions "under which there will be afforded useful employment opportunities, including self-employment, for those able, willing and seeking to work, and to promote maximum employment, production, and purchasing power," 32 the Act reflected the commitment on the part of the federal government to give attention to "maximum employment" and to fit this need into the overall economic picture. But this picture also included policies directed toward protecting the high profits of the largest corporations, fostering a climate for the enterprising, and building a hedge against inflation. In a word, the Employment Act was to be consistent with the needs of an economic system which required unemployment.

The defense contract system guaranteed workers a role of sorts in the national security system. In the fifteen-year period from 1959 to 1974,75 percent of federal government purchases of goods and services was for military purposes. ${ }^{33}$ Since it was assumed that Congress would not spend on public services, military expenditures were used as the economic tool to hedge against catastrophic depression. They have always been seen in this context by

29. Gehlen had been a senior planner for "Operation Barbarossa," the German invasion of the Soviet Union. E. Spiro [E. Cookridge], Gehlex: Spy of the Century 42 (1972).

30. R. Niebuhr, Christian Realism and Political Problems _ (1953). Niebuhr was the senjor advisor to the Policy Planning Staff of the Department of State during the crucial early stages of the Cold War. For a sympathetic account of his pre-World War II views, see Nichols, Reinhold Niebuhr, Prophet in Politics, in Responsibility of Power 370 (L. Krieger \& F. Stern eds. 1967).

31. Employment Act of 1946, 15 U.S.C. $\$ 1021$ (1970). A Senate version which committed the nation to full employment and guaranteed a right to employment was defeated in the House and deleted in conference committee. U.S. Code CoNg. Service, 79th Cong., 2d Sess. 1068 (1946).

32. 15 U.S.C. $\$ 1021$ (1970).

33. H. GinsBerG, supra note 18, at 9-16. 
policy planners and government economists. However, the major reason for low unemployment figures during the postwar to 1974 period is directly related to war and war preparations. As Keynes said, a capitalist economy could be helped through "pyramid building, earthquakes and even wars." 34 The pyramid builders of the defense industry were to be found in aviation and electronics, although other giants were involved. According to the staff economist of the Joint Economic Committee, "[i]n 1972, the 100 largest defense contractors received 24 billion dollars in contract awards, amounting to 72.1 percent of the total awarded. The top 10 contractors received nearly half (47.8 percent) of the value awarded to the top 100 and 31 per cent of all awards." 35 It should be noted that defense acquisition no longer picks up the unemployment slack. Indeed, in western countries there is now a correlation between high military expenditures and high unemployment. ${ }^{36}$ This is related to the fact that defense technology requires fewer workers.

While the Employment Act of 1946 at least gave the illusion of worker participation in the economic well being of the United States, the Taft-Hartley $\mathrm{Act}^{3 i}$ placed quite explicit limits on the power of organized labor. The wave of strikes between 1945 and 1947 had aroused fears of the growing strength of unions. In reaction to this showing of union power, the Taft-Hartley Act implemented a right to refrain from organization and concerted activities, made it clear that employers may express their opinions about unionism, outlawed the closed shop and subjected the union shop to certain limitations, and proscribed a number of union unfair labor practices, including secondary boycotts and jurisdictional strikes. ${ }^{38}$ In short, the Taft-Hartley Act served as the instrument "to block union organization, to weaken unions and to interfere with free collective bargaining." ${ }^{39}$ The law also kept communists from holding leadership positions in unions.

Nevertheless the position of the American worker substantially improved over the cold war period from his/her position during the depression. " The overall size of the economic pie was ever increasing, but the American dream, made tangible by this economic growth, masked the question of who would slice the shares. An important, indeed crucial, actor in selling the American dream was the President.

\footnotetext{
34. J. Keyes, The General Theory of Employent INTerest and Money 129 (1936).

35. Office of the Assistant Secretary of Defense (Comptroller), U.S. Dep't of Defense, 100 Largest Defense Contractors and Their Subsidiary Corporations, Fiscal Year 1974 (Oct. 9, 1974) (unpublished report available at Directorate for Information Operations, U.S. Dep't of Defense).

36. Tobin, On the Economic Burden of Defense, in Defense Science \& Pubi.ic Party 38 (E. Mansfield, ed. 1968).

37. Labor Management Relations Act, 29 U.S.C. $\S 141-97$ (1970).

38. Id.

39. Resolution of the AFL-CIO, quoted in A. Goldberg. Afl-CIO: Labor United 205 (1956).

40. P. TAFт, supra note 24 , at $587-88$.
} 


\section{B. The Presidency as the Rationalizing Instrument for Governing}

Since the New Deal, economic and political decisionmaking has shifted to the Executive. At first it was thought by hopeful liberals and fearful conservatives that the Presidency was the instrument for bringing about social reform, in the face of a Congress which did not care to disturb constitutional stare decisis and which favored the power of local oligarchic groups and special interests. Of course, another analysis of the Presidency exists: It saved capitalism through the appearance of changing class relations and through enormous political efforts at rationalizing the long term interests of the largest corporate elements of the society with organized labor and government. ${ }^{41}$ Whichever point of view is taken, James Burnham's conclusion is correct: "Before and after 1933; before and after Franklin Roosevelt and the New Deal,-these mark the crossing of the political line." 42 The Presidency became the rationalizing instrument for the most powerful groupings in the society. By the beginning of Roosevelt's third term, it was clear that the corporations, and then the military, needed the Presidency as a fundamental instrument either to extend their power or to assure that they would receive as much as they formerly received in benefits from the society. In other words, the office of the Presidency was the victim of a deepening crisis in the political and economic structure in the course of which leaders of corporate, police, and military institutions sought action to "save" their class or interest.

If he is given certain legislative tools, it appears that a President can act unchecked by the theoretical restraints which were written into our Constitution and our political system. The President can act out of whim or in furtherance of a carefully laid out set of plans devised by "an inner circle of political outsiders . . composed of members and agents of the corporate rich and of the high military in an uneasy alliance with selected professional party politicians seated primarily in the Congress, whose interests and associations are spread over a variety of local societies." ${ }^{43}$ Congress has given the President those legislative tools and the task of being point man to save the "system" and to rationalize the various conflicting interests of ruling groups. ${ }^{44}$

It should be noted that first for economic reasons, and later for imperial ones, the United States has organized itself according to national emergency rules since 1933. There are some 470 provisions of the federal law that delegate to the President, and therefore his agents, extraordinary powers during states of emergency. This congressional delegation, coupled with so-called inherent powers of the President, gives him carte blanche to act as he sees fit:

41. J. O'CoNion, supra note 1 , at 49; M. RaskiN, supra note 4, at 134-39

42. J. BurNhaM, Congress and the AnericaN Tradtion 129 (1959).

43. C. Milıs, supra note 2, at 231

44. M. RaskiN, supra note 4, at 28 . 
"Under the powers delegated by these statutes, the President may seize properties, mobilize production, seize commodities, institute martial law, seize control of all transportation and communications, regulate private capital, restrict travel, and-in a host of particular and peculiar ways-control the activities of all American citizens." 45

Before Nixon, Americans believed that a President is someone above politics with no dependence on special interests. "He parades as the anointed custodian of the eternal values, the true spirit of the people who have been victimized by selfish warring cliques or threatened by alien and subversive mischief-makers." 46 Where, however, a President charges too much for his services, or where he attempts to undercut the bureaucracy which has its own links to large economic interests or to fashion his own group of oligarchs to replace those groupings which have dominant social voices, such a pretender may find himself in dire trouble. Thus, the power of a modern President rests on several elements. One is his willingness to rationalize class relations in the society. This must not be done by tampering with those who hold great agglomerations of property. If he is liberal-minded, he will put forward schemes of economic growth which supposedly render "unnnecessary" any redistribution plans. Additionally, until 1975, he was not to undermine the military and national security apparatus grouping. Finally he is to pay obeisance to constitutional forms such as Congress without threatening their existence. ${ }^{47} \mathrm{He}$ is to recognize their legitimizing function and find a means of coopting it into the national security apparatus or the lockstep of the great corporations. A President who acts accordingly can be assured of the support of established power.

It should be noted, however, that such a President may not have the support of the people or of the various issue-oriented groups that have developed over the last fifteen years. ${ }^{48}$ Two recent Presidents, Johnson and Nixon, mistook electoral support for real support in the sense of depth of commitment to them or their programs. Even though each won an election with over 60 percent of the recorded vote, neither had a broad mass base which believed in him or recognized a coherent and non-antagonistic set of goals. Both men finally had to depend on particular ruling cliques which vanished when they became too "hot." Nixon, for example, who admired deGaulle, had hoped in his second term to rule by decree as did deGaulle, but

45. Senate Special Comm. on the Termination of The National. Emergency, Emergency Power Statutes, S. ReP. No. 93-549, 93rd Cong., 1st Sess. 1, 7 (1973). See also M. Raskin, supra note 4 , at 29 .

46. G. Novack, supra note 4 , at 158 .

47. M. Raskin, supra note 4, at 18-25, 53.

48. L.B. Johssox, supra note 1. 
he was too arrogant. ${ }^{49}$ He told the ruling establishment once too often that it had lost the will to rule and that he intended to replace it with his own group. But his friends were too weak to help him. Johnson, the neo-populist, reflected the missionary contradictions and antagonisms of American life within himself and his own policies. He wanted to put a carpet on everyone's floor in America, turn Indo-China into little Johnson City, overcome a measure of racism by bringing blacks into the American consensus, tame a new capitalist class from the Southwest, and make educational opportunity the instrument to forge a middle class. He thought all of these groups could mediate their differences and be united by American imperialism. ${ }^{50}$ But Johnson failed at stabilizing class relations, which he hoped to ameliorate by folding them into either a war or a harmonious society of individualists and opportunists. Cities went up in flames, the universities revolted, a terrifying war was fought for an imperial bureaucratic purpose, and Johnson found himself governing with Walt Rostow and the Joint Chiefs of Staff as his sole supporters.

\section{1 \\ Effect of the National Security State in UNDERMining ThE RULE OF LaW}

During the cold war period, the President and his immediate entourage became the brokers for the illegitimate power wielded by the CIA, the FBI, and the various gangs within them. They also sought to use these groups for their own purposes. The powerful seek maximum flexibility for their objectives. Ad hoc committees threaded the line between legitimacy, illegality and crime. ${ }^{51}$ Much of the time of a President and his advisors was spent curbing or ratifying the excesses of lower level bureaucrats emboldened by the imperial stance and the shroud of secrecy. ${ }^{52}$ Thus, for example, after the CIA's failure at the Bay of Pigs, the President, the Attorney General, and McGeorge Bundy undertook to control the national security bureaucracy through Maxwell Taylor and presidentially appointed committees. This "reform" more deeply implicated the Presidency in paramilitary and criminal affairs.

It should be noted that the entire framework of "maximum flexibility" for leaderships and the national security bureaucracy is meant to encompass both domestic and foreign activity. The control techniques which war and cold war Presidents sanctioned against the poor and the "subversives" at home, and which had been transported abroad during the cold war, were used as well

49. M. Raskix, supra note 4, at 38-39.

50. See, e.g., Johnson, My Political Philosophy, I TEx. Q. no. 4, at 17. 17-22 (1958).

51. R. Stavins, R. Barnet, \& M. Raskin, supra note 1, at 194-252; Hearings on S. Res. 21 Before the Senate Select Comm. to Study Governmental Operations with Respect to Intelligence Activities, Vol. 7: Covert Actions, 94th Cong., Ist Sess. 1-136, 148-210(1975).

52. Id. 
against the middle classes, the bureaucracies, and finally the leaders of the major political parties.

The FBI, as well as other police agencies of the federal government, proceeded to enforce the Procrustean bed of anti-left conformist ideology inside and outside the government. President Truman's Executive Order 9835, issued in March of 1947, required loyalty oaths of government officials. ${ }^{53}$ Many who held positions in institutions such as labor unions, universities, and the media were purged. By 1949 they found themselves eliminated from policy debates on the character of American society, treated as objects of contempt or benign tolerance. (As we shall see, the nature of the debate which came to take on new and surprising forms in the nineteen sixties was not contemplated by the national security state and its apparatus.) The effect of the Truman loyalty probes and those later undertaken by Senator Joseph McCarthy and J. Edgar Hoover was to enforce a view of the world based on hatred of "communism," and to prepare an automatic defense of corporate capitalism as the reason for American prosperity and the justification of American military adventures and alliances, both covert and overt. To this end the national security state was dedicated.

In Powers of Goverment, Bernard Schwartz outlines three fundamental elements of the rule of law: "1) The absence of arbitrary power; 2) The subjugation of the State and its officers to the ordinary law; and 3) The recognition of basic principles superior to the State itself."54 The assumption of Schwartz and others is that the rule of law is crucial to the existence of representative democracy. Even for the radical revolutionary Thomas Paine, the law was king: "Let a crown be placed thereon, by which the world may know that, so far as we approve of monarchy, that in America the law is king." 5 ,

\section{A. Arbitrary Power}

We shall see that the national security state and the rule of law are mortal enemies. In the first place, by its nature and the mission which it has set for itself, the national security state apparatus needs arbitrary power. Such power has its own code, which is meant to govern or justify the behavior of the initiated-after the fact. It operates to protect the state apparatus from the citizenry. And in its defensive form it is hidden under instant and specious doctrines such as executive privilege. ${ }^{56}$ This apparatus seeks to cede to the

53. Exec. Order No. 9835, 3 C.F.R. 627 (1943-1948 Compilation).

54. B. Schwartz, I The Powers of Governuest 26 (1963).

55. T. PAINe, Common Sense: Addressed to the Inhabitants of America [A New Edition 1776], in Common Sense and Other Political. Writings 332 (N. Atkins ed. 1953). Common Sense lays out the theory of natural rights, law and independence which the new nation applauded. See generally C. Beard \& M. Beard, The Rise of American Civilization 237 (2d ed. rev. \& enl. 1947).

56. Alas, Chief Justice Burger in his opinion, United States v. Nixon, 418 U.S. 683 (1974), does nothing to limit either executive privilege or confidentiality. See generally, Cotter, Legislative Oversight, in Congress THE First Branch 25, 55 (A. de Grazia ed, abr. ed. 1967). 
discretion of officials the power of the nation's citizens to manage their future or participate with others in that management. Government officials attempt to control the kinds of politics and citizen activities which they do not favor. They see no distinctions among geographic boundaries and are apt to operate in essentially the same way against Americans and non-Americans. Thus, the attempt of the CIA to assassinate Patrice Lumumba in the Congo is directly analogous to the FBI's attempt to destroy politically Martin Luther King, Jr. in the United States. President Nixon's sanctioning of the decisions of the 40 Committee to intervene and attempt to prevent the election of Allende through bribe offers and other means is strikingly similar to the methods CREEP used in Nixon's re-election campaign or to methods used against the United States Socialist Workers Party. ${ }^{57}$

The police agencies have attempted to serve as a brake on the political process. The COINTELPRO programs of the FBI have employed an astonishing variety of means to disrupt the activities of groups which sought to exercise their participatory rights. Programs like Operation Hoodwink were meant, for example, to incite organized crimes against the Communist Party, to entrap war objectors into undertaking bombings as in the case of the Camden, New Jersey draft board affair, and to break up human and social relations by sending forged documents and threatening letters to victims of federal and local police enterprises. ${ }^{58}$

Break-ins, burglaries, wire-taps and buggings on the citizenry have been a central aspect of the work of the FBI as they have undertaken to humiliate, ridicule, and harass civil rights workers, anti-war groups, radicals, conservatives, and any grouping which did not share the assumptions or the influence of those "in charge." ${ }^{9}$ And the CIA has taken pride in training local police in bugging, photo surveillance, and surreptitious entry 6 " These incidents are reminiscent of the struggles in Italy under Mussolini in the 1920s. Indeed, it may be said that the virus of totalitarianism has spread from one nation to another in the twentieth century with no exception granted to the United States either by God or its leaders. ${ }^{61}$

An important fact [in the case of Mussolini's Italy] is that the fascist squadrons had at their disposal . . not only the subsidies of their financial backers

57. Chomsky, Introduction, in COINTElPRO: The FBI's Secret War oN Political. Frefod 3-26 (C. Perkus ed. 1975); Senate Select Comis. to Stldy Governiental Operations with Respect to Intelligence Activities, Alleged Assassination Plots Involving Foreign Leaders, S. ReP. No. 465, 94th Cong., 1st Sess. 19-67 (1975); [cite source alleging harassment of Socialist Workers Party].

58. In COINTElPRO: The FBI's Secret War ox Political freedom, supra note 57, at 119-71; Hearings on S. Res. 21, Vol. 6: Federal Bureau of Investigation, supra note 51, at 1151, Appendix 4.

59. See, e.g., Hearings on FBI Counterintelligence Programs before the Civil Rights $\&$ Constitutional Rights Subcomm. of the House Comm. on the Judiciary, 93rd Cong., 2d Sess. 10-47 (1974).

60. Ross, Surreptitious Entry, in The CIA File 93-108 (R. Borosage \& J. Marks eds. 1976).

61. D. Guerin, Fascism aNd Big Business 98 (1939). 
but the material and moral support of the repressive forces of the state: police, carabinieri, and army. The police recruited for the squadrons, urging outlaws to enroll in them and promising them all sorts of benefits and immunity. The police loaned their cars to squadron members, and rejected applications for arms permits by workers and peasants while extending the permits granted to fascists. The guardians of "law and order" had their orders to remain idle when the fascists attacked the "reds" and to intervene only if the latter resisted. Often the police collaborated with the fascists in preparing attacks on labor organizations.

This description of fascist strategy in Italy in 1921 is striking in its resemblance to the approach followed by the CIA, Kissinger, Nixon, and McCone in their successful attempt at bringing down the Marxist government of Allende in Chile: ${ }^{62}$

a) Collect intelligence on coup-minded officers; b) Create a coup climate by propaganda, disinformation, and terrorist activities intended to prowoke the left to give a pretext for a coup: (Cable 611 . Hq. to Sta., 10/7/70; c) 1 h form those coup-minded officers that the U.S. government would give them full support in a coup short of direct U.S. military intervention.

The line between criminal gangs and the police is crossed of ten in the national security state. The purposes may appear obscure to the average lawabiding citizen, but the process of tyranny can be felt by the body politic which finds reason and justice suspended for power and domination. ${ }^{63}$

One FBI provocateur resigned when he was asked to arrange the bombing of a bridge in such a way that the person who placed the booby-trapped bomb would be killed. This was in Seattle where it was revealed that FBI infiltrators had been engaged in a campaign of arson, terrorism, and bombing of university and civil buildings, and where the FBI arranged a robbery, entrapping a young black man who was paid $\$ 75$ for the job and killed in a police ambush.

And the San Diego Union, on January 10, 1976, reported that the Secret Army Organization which fire-bombed cars, burglarized the homes of antiwar protestors, and ransacked offices, was "a centrally designed and externally financed infrastructure designed for terror and sabotage." According to the San Diego Union, the acts took place in 1971 and 1972 and were "sanctioned by the nation's most powerful and highly respected law enforcement agency, the Federal Bureau of Investigation.." ${ }^{44}$ (This allegation has been denied by the FBI. $)^{65}$

The attempt by holders of arbitrary power to inhibit people from exercising their participatory rights is invariably accompanied by forms of personal harrassment against people who have no interest in the exercise of their

62. Alleged Assassination Plots Involving Foreig. Leaders, supra note 57, at 234

63. Chomsky, supra note 57 , at 15 .

64. San Diego Union, Jan. 10, 1976, quoted in Newspaper Says FBI Funded Terror Unit, Washington Post, Jan. 11, 1976, at A2, col. 1.

65. Newspaper Says FBI Funded Terror Unit, Washington Post, Jan. 11, 1976, at A2, col. 1. 
rights. Their interest is limited to carrying on ordinary functions of life. Here the arbitrary power of the national security apparatus operates less obviously, in a more automatic and, to the victim, less obtrusive way. We see the building up of files on a person which are used for a variety of purposes such as to engage in blackmail or to control possibilities of future employment for the object-victim. This course of bureaucratic behavior is especially popular in a period where bureaucracies grow larger, computers more sophisticated, and leaderships more insecure. It is punctuated with the predictable danger in which vying leadership elites use police and other records as weapons to destroy their opponents or settle old scores. Such activities are common practice in the bureaucracy of the national and "internal" security apparatus. ${ }^{66}$ And there is nothing in public law which sets limits for the FBI or, indeed, suggests that authority exists for carrying on its comprehensive surveillance activities in the area of "subversive activities." 6 i

\section{B. Officers Above the Law}

In the Dual State, specifically rejected by American law, "[l]egal concepts are not applicable to the political sphere, which is regulated by arbitrary measures, in which the dominant officials exercise unfettered discretionary prerogatives." ${ }_{68}$ The national security state is the American version of the Dual State. Within the national security agencies we may discern several levels of para-legal and illegal activities.

At one level the national security apparatus operates according to a paralegal structure which has its own administrative and self-justifying system. It is

66. Inquiry into the Destruction of Former FBI Director J. Edgar Hoover's Files ث FBI Recordkeeping, Hearing before a Subcomm. of the House Comm. on Gov't Operations. 94th Cong., 1st Sess. 59 (1975) (hereinafter cited as Hoover Files Hearings).

67. Mr. NitTle. [Counsel of the House Committee on Internal Security] Mr. Maroney, I see literally nothing specific in the directives of Presidents Roosevelt and Truman which informs us or the FBI as to the precise mission to be fulfilled by the Federal Government in undertaking investigations of subversive activities. Has this been spelled out in any other published or unpublished memoranda or directives:

Mr. Maroser. [Deputy Assistant Attorney General] I think we are back to what we were talking about earlier as to particular directives to the Attorneys General from time to time.

Mr. NitTle. I see nothing in title 28, CFR which informs us of the precise mission to be fulfilled. Wouldn't that help to inform the FBI of the scope and nature of the investigations to be undertaken:

Mr. Maroney. The FBI has its own manual. I am trying to tell you the Attorney General has from time to time provided them with instructions as to what to investigate and what to furnish the Department in this area, but it is not wrapped up in a nice little package.

Hearings on Domestic Intelligence Operations for Internal Security Purposes Before the House Comm. on Internal Security, 93d Cong. 2d Sess., pt. 1, at 3446-48 (1974).

68. B. ScrwarTz, supra note 54 , at 
"private," having its own standards. Thus, the now famous 40 Committee is an example of an attempt to draw the various police, military, and criminal forces at the command of the leadership into a private and self-justifying administrative system. "Beginning in 1955, the responsibility for authorizing CIA covert action operations lay with the Special Group, a subcommittee of the National Security Council (NSC) composed of the President's Assistant for National Security Affairs, the Director of Central Intelligence, the Deputy Secretary of Defense and the Undersecretary of State for Political Affairs." ${ }^{\text {"9 }}$ Today this group, known as the 40 Committee, has been expanded to include the Chairman of the Joint Chiefs of Staff. This part of the national security apparatus operates according to its own rules and regulations, taking little or no account of public law and asserting its own definition of national security and national interest-a definition which is invariably ruling class oriented. We may refer to it as "lightly-covered" because it may or may not surface from time to time, as in the case of the 40 Committee. When it does surface, it seeks to justify its actions by embracing principles of positive law and of the Dual State.

On another level, the national security state carries on activities which are flatly illegal. At this level criminal behavior becomes an important operational instrument. National Security Defense Memorandum 40 of 1970 points out that the intelligence apparatus must be ready for all contingencies and must have responses basically researched and in being. ${ }^{70}$ In other words, preparing for criminality and involving or nurturing criminal behavior must be a part of the costs of the national security state since it is never clear when such will prove useful. This includes forgery and counterfeiting, assassination, the employment of known criminals, and so on. ${ }^{71}$

CIA must necessarily be responsible for planning. Occasionally suggestions for action will come from outside sources but, to depend entirely on such requirements would be an evasion of the Agency's responsibilities. Also, the average person, both in government and outside, is thinking along normal lines and to develop clandestine cold war activities properly, persons knowing both the capabilities and limitations of clandestine action must be studying and devising how such actions can be undertaken effectively.

This kind of thinking goes beyond the para-legal procedure. It gives rise to plans and actions of a frightful nature. An unlimited choice of means has been extended to agents or hired contract officers. Thus, the sober William Colby planned and carried out the Phoenix program, which resulted in the

69. Alleged Assassination Plots Involving Foreign Leaders, supra note 57, at 10. See also United States v. United States Dist. Court, 407 U.S. 297, 324 (1972) (Douglas, J., concurring).

70. See text accompanying note 14 supra.

71. Directive of the National Security Council, NSC 5412/2, quoted in Alleged Assassination Plots Involving Foreign Leaders, supra note 57, at 9 n.4 (emphasis added). 
killing of some twenty thousand Vietnamese. They were killed because they were ostensibly part of the "Viet Cong's infrastructure."72

Another example of the policy criminal is the imaginative General Lansdale. He was put in charge of the MONGOOSE program to overthrow Castro through covert means. He recommended exploiting the potential of the underworld in Cuban cities to harass and bleed the community control apparatus. Added to this plan was another suggestion (among thirty-one other planning tasks) to utilize biological and chemical warfare against the Cuban sugar crop workers. ${ }^{73}$ (It should be noted in passing that such activities are proscribed by international law and would be so treated under the Personal Accountability Bill introduced by thirty-eight members of Congress. $)^{74}$

The Special Group minutes on June 19, 1963 suggest the manner in which the Executive undertook war and warlike activities on its own initiative, pulling itself and the government into unaccountable policy crimes. At a meeting in which McNamara, General Kee, Harriman, McCone, Desmond Fitzgerald of the CIA and McGeorge Bundy were present, a sabotage program was set out by the CIA to the members of the Special Group. It was to be directed at "four major segments of the Cuban economy:" a) electric power; b) petroleum refineries and storage facilities; c) railroad and highway transportation; and d) production and manufacturing. Raids were to be conducted from outside Cuba, using Cuban agents under CIA control. Missions would be staged from a United States key. ${ }^{75}$

Here are officers of the government who have statutorily defined responsibilities in the constitutional order, acting in their hidden role as officers of the Dual State. They cannot be reached or controlled through constitutional or legal means. At the first meeting of the National Security Council in December 1947, "covert operations" were authorized, giving the go ahead to criminal action. ${ }^{7 t}$ It would take us too far afield to analyze the social class bias of the views held by this and other "executive committees" which assume a consensus by the members of the government for the carrying out of actions against the underprivileged and powerless persons of the earth. What are we to make of an ambassador, Korry, who said that once Allende the marxist was elected President, the United States would "do all within our power to condemn Chile and the Chileans to utmost deprivation and poverty. . . "? Or of President Nixon and Secretary of State Kissinger who, having been emboldened by various multinational corporations such as IT\&T and PEPSICO, pur-

72. The CiA File 190 (R. Borosage \& J. Marks eds. 1976).

73. Alleged Assassination Plots INvolving Foreig. Leaders, supra note 57, at 139-69.

74. H.R. 8388, 94th Cong., Ist Sess. (1975). A memorandum in explication of the bill containing a detailed analysis of its contents appears at $121 \mathrm{CoNG}$. REC. H6396 (daily ed. July 8, 1975).

75. Id. at 173 .

76. See NSC 5412/2, supra note 71 .

77. Alleged Assassination Plots Involving Foreign Leaders, supra note 57, at 231 n.2. 
sued another attempt to bring down Allende, an attempt which was operated through the White House and even kept secret from the 40 Committee?is According to Kissinger, this plan involved a group that was unknown to others for "reasons of security" and charged with the responsibility of working with the Chilean military in bringing about a coup against Allende. ${ }^{79}$ They succeeded. Suffice it to say, and I will return to this point, the consensus which existed fifteen years ago among elites does not today exist among them. And more to the point, this consensus is no longer shared by the American public as a whole.

The cultural hegemony in which all classes internalized the world view of the ruling elite has been broken-as it had to be in a democracy. It is no wonder that this hegemony is broken, for the rule of law is challenged directly by the very operators of the state. Thus, as an example, former Vice President Nelson Rockefeller pays an average of 10 percent tax on his total income, approximately equal to the amount paid by the average worker who earns $\$ 8,000$ a year. ${ }^{81}$ Simultaneously, as Chairman of the Commission to investigate the CIA, Rockefeller attempted to legitimize the para-legal activity of the national security apparatus by turning crime into law. And in his guise as statesman, Rockefeller was representative of those oligarchs who believe in weak legislatures, favoring government by authorities who are responsible to no elected officials or legislatures but merely to the most powerful economic and military elements of the society. ${ }^{81}$

According to Justice Brandeis, "[a]t the foundation of our civil liberties lies the principle which denies to government officials an exceptional position before the law and which accepts the same rules of conduct that are commands to the citizen." 82 Accordingly, everyone is subject to the ordinary law and amenable to the rules of the courts. Ostensibly, this would be the one means of guarding against the Dual State. But the role of the courts is exceedingly limited with regard to the national security apparatus, thus permitting the expansion of its para-legal and illegal activities. We know when examining the decisions of the courts that the judiciary has handled precious few cases involving the CIA or the National Security Agency (NSA). The courts are frightened of the Dual State, hoping that the problem will go away if no attention is paid to it. Furthermore, where such cases have been presented to the courts,

\footnotetext{
78. Id. at 250 .

79. Id. at 246-55.

80. Conflict of Interest Group, Institute for Policy Studies, The Disability of Wealth, An Inquiry into the Nomination of Nelson Rockefeller as Vice-President (Nov. 1974) (unpublished report available at the Institute for Policy Studies, 1909 Que St. Washington, D.C.).

81. Id.

82. [Brandeis source], quoted in B. Schwartz. supra note 54. at —. But cf. Alleged AsSassination Plots Involving Foreign Leaders, supra note 57 , al 9.
} 
judges have been reluctant or unable for institutional reasons, to rule against the secret agencies or inquire as to their activities. ${ }^{83}$

Why does the doctrine of Marbury r. Madison stop at the gates of Langley, Virginia? One reason is that secret agencies specialize in lying. Indeed, they are so structured by mission and organization as to give credence to the view that as much as they are the children of Allen Dulles and J. Edgar Hoover, they are also the descendants of Epimenides. A stock in trade of the CIA has been plausible deniability. This "doctrine" is meant to protect operatives "from the consequences of disclosures" and "to mask decisions of the President and his senior staff members." 84 The masking process is "designed to allow the President and other senior officials to deny knowledge of an operation should it be disclosed." ${ }^{85}$ In other words, plausible deniability is a doctrine which encouraged the invention of false information or lies which will be acceptable to other government agencies, the courts, and the public, as well as to competing or uninformed groups within the secret agencies themselves. Related to the doctrine of plausible denial is the "need to know" principle. The operational effect of "need to know" is, as Richard Barnet has said, need not to know. ${ }^{86}$ In other words, the FBI and the CIA operate on the basis that various groups within their own agencies, including higher officials, have little idea of what others in the same chain of command are doing.

But democracy and its operative principle, the rule of law, require a ground on which to stand, and that ground is, as former President Ford said when he was installed as President, truth. ${ }^{8 i}$ In this regard the government has a higher duty to tell the truth than the citizen because it is the government which embodies the tradition and values of the body politic as a whole. Where the government lies or is so structured as to permit only lies and self-deception, it is clear that the governing process and the organization of power has become some other form than that originally intended or generally understood by the citizenry as the original constitutional form. The doctrines of "plausible denial" and "need to know" present problems of particular significance for the judiciary as enforcer of the rule of law, because with the development of the national security state, the duty of truth-telling has been substantially waived. Indeed, it is taken for granted that lies and masks are the official's tools for self and group protection.

83. Alfred A. Knopf, Inc. v. Colby, 509 F.2d 1362 (4th Cir. 1975) cert. denied, 421 U.S. 992 (1974); Developments in the Law-The National Security Interest and Civil Liberties, 85 Harv. L. REv. 1130,1134 (1972).

84. Alleged Assassination Plots involving Foreigi leaders, supra note 57 , at 11.

85. Id. at $11-12$.

86. R. Stavins, R. BarNet, \& M. Raskix, supra note 1, at 246.

87. Remarks of President Gerald R. Ford following his swearing in as 38th President of the Lnited States, 10 Weekly Comp. of Pres. Doc. 1023, 1024 (Aug. 9, 1974 ). 
One example of the kind of falsification that is routine within the national security apparatus is the GATTO incident. The U.S.S. GATTO, against orders, drifted within one mile of the Soviet coast. A Soviet sub rammed the GATTO somewhere between the Straits and the White Sea. The GATTO was ready to fire a nuclear missile at the Russian sub, but the GATTO escaped without needing to do so. The officers of the ship were requested to file two sets of reports. One set was to consist of six copies describing the real incident as it actually occurred, the other set to be twenty-five copies falsifying the incident. The Pentagon admitted filing the falsified reports, but said that it filed the true report with the 40 Committee. However, when interviewed, officials could not locate or remember any reports about the GATTO ${ }^{88}$ There have been at least four mid-ocean collisions between United States Navy and Soviet nuclear powered and nuclear weapon carrying submarines since the mid 1960s. These were ostensibly intelligence operations which could have easily resulted in nuclear disaster. ${ }^{89}$

Since "unacceptable" acts - that is, actions that are constitutionally, legally, or morally questionable-are denied by the agency as a matter of course, there has been no way for courts to test the veracity of statements of the secret agencies. For example, how are we to know when the FBI engaged in a particular course of conduct such as wiretapping, burglary, or entrapment? We now learn that the FBI kept at least two separate sets of books. One set that is available to the courts reflects the FBI's "acceptable" or "legitimate" purposes. The other set appears to have been less pretty, and was unknown except to the initiated. ${ }^{90}$ To the extent it is written, this set apparently shows the actual operations of the FBI and special groups, their special missions, and special purposes undertaken for themselves and for special friends. But this is not the record which the courts receive. Marbury is defeated by national security practice.

\section{Basic Principles Superior to the State}

According to Schwartz the third element of the rule of law is a recognition that there are principles which are superior to the state itself. This is an important safeguard against legislatures that pass laws which may be criminal. It is also a justification for the citizenry to act in a civilly disobedient manner against laws or governmental acts which shock the conscience of the society. The history of the twentieth century is replete with para-legal orders for

88. Command Study Group, R. Stavins, Chairman, Study on U.S.S. GATTO, Problems of Nuclear Accidents 4 (Feb. 1974) (unpublished report available at the Institute for Policy Studies, 1909 Que St. Washington. D.C.).

89. Id. at $1-7$.

90. Hoover Files Hearings, supra note 66 , at 36-48. 
bombings, concentration camps, assassinations, and break-ins. ${ }^{91} \mathrm{~A}$ citizen does not affirm or assent to every proclamation, every law, every secret rule of a secret policy agency, whether it operates within the United States or abroad, nor does the citizen affirm every executive order which appears to operate under the color of the law. What we may discern instead is limited assent, a quality which must be continuously won from its citizenry by a government. It does so by doing justice and by recognizing human and natural rights as qualities of being which indeed define personhood.

Those generally shared notions of human rights seem to be engaged in a race against the inclinations of the national security state swollen with nuclear weapons. There exists a seeming willingness on the part of the bureaucracy, the military, and science to build and use weapons of mass destruction on hundreds of millions of people because they, as a group, or their leaders, do not see the world in similar ways as a rival set of leaders. This situation poses a question which cannot be dodged. ${ }^{92}$ What right does a state have to commit suicide for the people? This issue raised in its baldest form has yet to be considered either by the people, the Congress, or the courts.

It may be asked whether the rule of law can begin to deal with any of these issues. What help can citizens expect to have if they raise the question of whether the state can commit suicide for the body politic by its policy of mindless armament or its use of nuclear weapons to destroy whole classes of people?

The courts have attempted to recognize constitutional rights of the citizenry as they relate to equality of opportunity. They have also attempted to give proper credence to the civil rights of people, thereby recognizing "personhood" and those rights which attach to a person qua person as well as those which attach to a person qua citizen. This objective has not been shared by the police apparatus. Thus the FBI, throughout the period of the civil rights struggles of the 1960s, had the unfortunate habit of allowing the local police to beat and jail civil rights demonstrators. And the FBI as well as the CIA infiltrated black nationalist groups in the ghetto for the specific purpose of ridiculing and discrediting their organizing attempts. ${ }^{93}$ There was no recognition by the police agencies that the struggles of the civil rights movement were for natural and human rights. This is not surprising. To guarantee such rights would mean that their own activities would have to come under strict scrutiny and finally be dismantled in favor of local neighborhood and community police. It should be noted that, based on a study of the Media Papers,

91. F. Neumann, Behemoth 452-58 (1942); T. Becker, American Government, Past, Present, Future 319 (1976); R. Stavins, R. Barnet, \& M. Raskin, supra note 1, at 284-85 (explaining the use of para-law).

92. M. Raskin, supra note 1 , at 47-76.

93. In Cointelpro: The fBI's Secret War on Political Freedom, supra note 57. at 9-17. $110-18$. 
stolen from the files of the FBI in Media, Pennsylvania, 40 percent of the FBI's time is spent in harassing and keeping tabs on political groups which sought some measure of recognition of their personhood. ${ }^{94}$ It is hardly surprising that the national security apparatus, built as it is upon principles of unaccountability, secrecy, ultra-allegiance to the state, and willingness to lie to the courts and legislatures, is unconcerned with human or natural rights. ${ }^{95}$ (One may recall Ambassador Popper's attempt to criticize the Chilean junta for disregarding human rights and torturing prisoners. Kissinger instructed Popper to stop giving the junta political science lessons. $)^{96}$ Yet within the American Constitution there is the seed of a radical understanding of the rights of the people. Under the ninth amendment the rights of the people cannot be disparaged, i.e., they cannot be disparaged by the government, the secret apparatus of the government, the gangs which operate within the secret apparatus, or the President in an effort to commit mass suicide. How is this process to be interrupted? It is only in a continuous dialogue from the "grass roots" that imperialism can be interrupted. Less than forty years ago the antiimperialist Ludlow resolution, ${ }^{97}$ which almost became federal law, stated that wars could not be declared without a referendum of the people.

\section{III}

Imperialism as a Self-Justifying. Instrument of Domestic Policy in the National Security State

America's historic involvement with imperialism is a complex one and is beyond the scope of this paper. It is clear that the imperial desire has played an important and continuous role throughout American history, ebbing and flowing with the appetites of different leadership groups. Nevertheless, it was not until the second world war that imperialism was seen by an entire ruling elite as a means of permanently resolving internal problems of the United States while exporting its cultural values around the world. At the turn of the century, Brooks Adams saw imperialism as the only way to deal with internal American contradictions. Less than two generations later, a leadership elite saw American imperialism as a destiny "thrust" upon it which could save the United States and the world on their terms. It was the United States' turn to take the baton from the United Kingdom as the purveyor of the West's values and traditions. If world empire was the means to protect these values, so be it. So spoke Walter Lippmann to a more parochial-minded Charles Beard, and Reinhold Niebuhr to his former pacifist allies such as A.J. Muste. ${ }^{98}$

\footnotetext{
94. See generally id.

95. See generally id.

96. New York Times, Sept. 28, 1974, at 9, col. 8 .

97. M. Raskix, supra note 4 , at

98. Beard, Giddy Minds and Foreign Quarrels, 179 HARPER's MAG. 337, 349 (1939): Lippmann, What Rome Was to the Ancient World, LIFE, June 5, 1939, at __; R. Niebuhr, Child Rex Of LichT
} 
To some extent this attitude was an ideological change for many Americans. As Selig Adler, the historian, has said, "the isolationist impulse has been woven into the warp and woof of an American epic."99 Dean Rusk once said in a moment of candor that the American people were "carried kicking and screaming by its leadership into world responsibility." 100 Like Adler, he believed that Americans were by nature isolationist, although there is little in their history which suggests this conclusion. On the other hand, there has been a middle-western antipathy to imperialism reflected in populism and La Follette progressivism. ${ }^{101}$ To counter this American antipathy to ward imperialism, the leadership cloaked its actions in the language of beneficent internationalism and explained how the American isolationists brought on World War II with their negative attitudes. The internationalism of Dean Acheson, Richard Bissell, and Will Clayton had a distinctly material cast to it. Thus, for example, 90 percent of the funds given by the United States to Marshall Plan nations were spent in the United States. And as Undersecretary of State, Clayton, a millionaire cotton broker, saved the southern cotton industry at a precarious time. ${ }^{102}$

Nevertheless, an aura of excitement was created around the imperial enterprise in bureaucracy. Officials believed in the importance of their work, for they thought that they were continuing a crusade. In personal terms middle class achievers saw imperial activities as the new frontier for their energies and ambitions. In poor countries, western methods of organizing people were embraced by local bureaucrats and elites trained by the Americans. Latin American and Asian nations organized their armed forces and internal security systems along lines laid out by the members of the national security apparatus. For close to twenty years it was assumed that the disagreements in public policy were not over ends, but merely means. Liberal ideologists like Arthur Schlesinger, Jr. referred to the "vital center," intending to legitimate the narrowness of debate. The task of liberals was to screen out views that did not fit into the corporate liberal consensus, the ground upon which the national security apparatus was constructed. ${ }^{103}$

The national security bureaucracies and policy leadership invented selfjustifying "facts," premises, theories, and hypotheses. It is well to mention

\footnotetext{
ANo Childrex of Darkiness 10 (1944); Schlesinger, Theology and Politics from the Social Gospel to the Cold War, in INTelefctual. History iN AMerica 158 of Foreword (C. Stout ed. 1968).

99. S. Adler, The Isolationist Impulse: Its Twentieth Century 15 (1957).

100. R. Stavins, R. Barnet, \& M. Raskin, supra note 1, at 289; H. Graff, The Tuesday CABINET 135 (1970).

101. See generally $1 \& 2$ B. La Follette \& F. La Follette, Robert M. La Follette, June 14, I855-JUNE 18, 1955 (1953).

102. C. Solberg, Riding High, America iN Thf Cold War 77 (1973).

103. A. Schlesinger, Jr.. The Vital. Center: The Politics of Freedom 156, $182-85,255-56$ (1949).
} 
some of these statements so that we are aware of the shallowness of thought which guided the actions of officials. Such rag-tag ideas were the ideological wrapping to mask narrow class interests, ungrounded "idealistic" purposes, and one-dimensional theories of human behavior. It was hoped that if the slogans were said enough times the passive audience would salivate to them like Pavlov's dogs, without critical concern. Here are some of the ideas and official "insights": From 1967 onward the Department of Defense argued that it would not end the war in Vietnam because of the terrible bloodbath which would ensue. Another fiction was that the United States had no choice but to fight limited wars in Southeast Asia, Africa, or wherever so that it would not be required to fight a world war to make its point. ${ }^{114}$

These homilies which have so guided official thinking and which have cost the lives and property of millions of people are now unmasked and shown to be false. As Hannah Arendt has said:"1"

Unable to defeat, with a "1000-to-1 superiority in fire power," . . a small nation in six years of overt warfare. unable to take care of its domestic problems and halt the swift decline of its large cities. having wasted its resources to the point where inflation and currency devaluation threaten its international trade as well as its standard of life at home, the country is in danger of losing much more than its claim to world leadership. And even if one anticipates the judgment of future historians who might see this development in the context of twentieth-century history, when the defeated nations in two world wars managed to come out on top in competition with the victors (chiefly because they were compelled by the victors to rid themselves for a relatively long period of the incredible wastefulness of armaments and military expenses). it remains hard to reconcile oneself to so much effort wasted on demonstrating the impotence of bigness. . . .

By 1974 the humpty-dumpty fantasy world could not long be sustained. As a coup against the coup was generated against Nixon, and as United States forces left Indo-China bewildered, pleased, and beaten, the era of false consciousness ended. It is not likely that the citizenry will again accept the cliches and self deceptions of the corporate and bureaucratic institutions of the society.

This is particularly true in the cities where the tax structure and the habits of mind of the oligarchs and national security managers have imposed great burdens. ${ }^{106}$ The public life of the cities and their possibilities as organic livable units have been badly damaged by the national security state's voracious capital requirements, its need of labor talent, and its habit of turning the

104. J. Warburg, The Uxited States 1N The Post-Wak Worlo 184 (1966). Warburg discusses the Rusk doctrine in which the United States can get along militarily or otherwise to withstand Communism.

105. H. Arendt, Crisis of the Republic 33-34 (1972).

106. L. Mumford, The City is History 533-40 (1961); Study Group on the Federal Budget. Institute for Policy Studies, The Problem of the Federal Budget (Nov. 1975) (unpublished report available at the Institute for Policy Studies, Washington, D.C.). 
attention of the people to abstract and glorious adventures which escape the hum-drum. The imperial enterprise has enabled people to identify with the unauthentic. The dull work of making places that children could play in, or buildings that people could live and work in, was never able to match the overthrow of Arbenz or the romance of making nuclear weapons. The social energy of the nation went to the moon shots, wars and their preparation, or paving highways to escape the cities. The nation manifested its choices in the development of imperial architecture as in Albany, New York or Washington, D.C.

The contradiction between the city and the national security state will grow greater over the next decade, as it becomes clear to all that to retain the imperial conceit, the alliances, the bureaucratic apparatus, the global corporations, and so on, greater and greater sacrifices will be required of the people in the cities-especially working and middle-class. ${ }^{107}$

Leaving aside the misplaced Niebuhrian fervor or the subtle racist and elitist bias of United States leadership, a conservative pragmatist might well begin to question the entire imperial anti-communist enterprise from the enterprise's own assumptions and goals. Imagine that you were a follower of the conservatism of Robert Taft, Jr. What might you now say? In the space of twenty-five years, the following events have occurred:

1. China became communist even though the United States committed billions in material, employed Marines on the side of the Kuomintang cause, and attempted to subvert the Communists and isolate them. Twenty-five years later Chinese leadership was recognized by the United States on its own terms. American leaders journey to China for a blessing from the heroes of the Long March and are treated to anti-Soviet lectures.

2. Twenty years ago the Korean war, in which the United States committed 475 thousand troops at one time, was fought to a standstill, without victory. The United States lost 47 thousand soldiers in that police action which ended up sorely testing civilian control over the military. ${ }^{108}$ Needless to say, the flames of McCarthyism were fanned by the war. A decade later, with one American President, Lyndon Johnson, saying that the United States had no interests in Indo-China, the United States spend $\$ 160$ billion, lost 60 thousand men, and wounded 250 thousand others, ${ }^{109}$ while internal contradictions in the American economy were made more obvious. ${ }^{110}$

3. The United States corporations, much in the manner originally sug-

107. L. MUMFORD, supra note 106, at 548-60.

108. R, Leckie, The Wars of America 858 (1968).

109. Office of the Assistant Secretary of Defense (Comptroller), U.S. Dep't of Defense, U.S. Casualties in Viet Nam, Jan. 1, 1961 - Oct. 31, 1975 (Jan. 15, 1976) (unpublished report available from Directorate for Information Operations, Dep't of Defense).

110. Raskin, Towards a Modern National Security Policy, in The Problem of the Federal Budget, supra note 106 , at 51 . 
gested by Donald Nelson in the mid-forties, ${ }^{11}$ seek markets for merchandise in the Soviet Union, believing that trade is the sine qua non for taming the Soviets and maintaining capitalism. Multinationals cursed Senator Jackson for his amendment to the Trade Act, saying that it has cost American companies $\$ 2$ billion in trade with the Soviets. ${ }^{12}$ In Portugal, meanwhile, American national security managers are faced with a choice of supporting either communism or socialism. Ninety miles from home the State Department and various groups within the foreign policy elite seek ways to open relations with the Cubans even as the Cubans insist that the United States give independence to Puerto Rico, and impoverished Trinidad supports Puerto Rican independence without a whisper of United States criticism. ${ }^{13}$

4. In Western Europe Henry Kissinger has fought a rear guard battle with the center parties, the Christian Democrats and members of the capitalist class who want to include the Communist party in governing coalitions of France and Italy. Even now there is evidence of multinational corporations helping the communist parties of Western Europe on the theory that it will benefit trade, while the CIA sent $\$ 6$ million to influence the elections. ${ }^{114}$ Italians point to the arrangement of FIAT with the Soviet Union, producing the Togliatti car in no less than a joint operating arrangement.

Against the background of events, would not the prudent imperialist, the anti-communist and liberal-minded oligarch, have cause to wonder at least for a moment at what he has wrought? Were the $\$ 2$ trillion spent on military aid and weaponry successful in preserving world hegemony? Is American society more "secure"? Have the Soviets acted less judiciously because the United States establishment fought in Indo-China and spends $\$ 100$ billion yearly on its defense? What we do notice is that the United States has isolated itself from the opinions of most nations. The United Nations General Assembly resolutions have found the United States often voting with virtually no other nation on matters of decolonization, trade, anti-apartheid, and so on, and yet, the United States cannot break free from the United Nations. The question which is then raised by the citizenry in neighborhood bars, church groups, and local business clubs is a very practical one. What has been the value of the imperial adventure to them, and to their community? The distribution of the tax burden is such that it is the poor and the middle classes which pay for the empire, not those oligarchs who benefit most from it. As Quincy Wright has said in

111. J. BLum, supra note 10 , at 285-86.

112. Interview with John T. Connor, Executive Vice President of the Trade and Economic Council, on NBC Television (Jan. 9, 1976).

113. Seminar given by Leslie Minigot, Director, Institute for International Relations, University of the West Indies, Port of Spain, Trinidad, at the Institute for Policy Studies, Washington, D.C. (Fall 1975). It must be noted that there is greater official and military interest in the Caribbean ostensibly to counteract the Cuban support for Puerto Rican independence.

114. The Village Voice, Feb. 16, 1976, at 85, col. 1 . 
his monumental Study of War, imperialism is not beneficial to a nation as a whole: ${ }^{115}$

\begin{abstract}
Imperialism, therefore, tends to attach an exaggerated importance to nationals engaged in political or economic activity abroad, regarding them as the pioneers of empire. "Imperial welfare" is, therefore, interpreted as requiring the protection not only of the various groups and interests in the home territory but, to an even greater extent, the protection of all or certain interests abroad. These "interests" are interpreted, however, not in the purely economic sense in which the individuals immediately involved may interpret them but rather in the sense of instruments for expanding the state's imperial domain, influence, and power. ...

Because of the costs of military and military armament. empires have seldom proved economically profitable for the population of the home country. The average plane of living of the Swiss and Scandinavian peoples without colonies has been as high or higher than that of the British and French people with great empires. It is possible that empires have served to maintain certain interests of the privileged classes and to provide a safety valve for the energies of a type of personality who might become leaders of revolutions in the home territory....
\end{abstract}

Thus, while imperialism may temporarily expand the opportunities for capitalism, its long-run effect is to bring about the same tendencies toward state socialism and militarism that nationalism inclines us toward.

There is an added horror which surrounds us. The world continues to suffer the consequences of Churchill's and Roosevelt's "foresight," that "in all the circumstances our policy should be to keep the matter [the atomic bomb] so far as we can control it in American and British hands and leave the French and Russians to do what they can."116 The national security state itself is predicated on atomic weaponry. Elsewhere in this essay I have adverted to the important role which nuclear weapons and military technology had in building the national security state. The lengths to which state apparatus sought blindly to insist on the guilt of the accused in the Oppenheimer and Rosenberg cases is instructive on this point. The judge in the Rosenberg case assured the Rosenbergs that they had caused the Korean war because they had "leaked" secrets to the Russians and that, in consequence, they had on their hands the blood of thousands of Americans. ${ }^{117}$ Of course such cases were used to justify and strengthen the security apparatus.

The attitude of protecting the secret of the bomb and using nuclear weapons as the first and final arbiter of state relations was established prior to its existence. In 1944, according to the historian Martin Sherwin, Niels Bohr tried desperately to get Roosevelt and Churchill to invite "Soviet participation in postwar atomic energy planning before the bomb was a certainty and be-

115. Q. Wright, A STudy of War 1189-92 (2d ed. 1965).

116. M. SHERWIN, supra note 12 , at 108 .

117. M. SChNeIR \& W. SChNeIR, INVITATION TO AN INQUeST 170 (1965). 
fore the war was over."118 He had wanted the Russians to be informed of the Manhattan Project and hoped for a situation in which scientists would be instrumental in bringing about a modus vivendi in nuclear armaments. For his troubles Churchill said of Bohr:11y

Enquiries should be made regarding the activities of Professor Bohr and steps taken to ensure that he is responsible for no leakage of information particularly to the Russians. I did not like the man when you showed him to me, with his hair all over his head, at Downing Street. How did he come into this business?.. . He says he is in close correspondence with a Russian professor. What is this all about? It seems to me Bohr ought to be confined or at any rate made to see that he is very near the edge of mortal crimes.

So now we have followed the conventional wisdom about holding on to the "secrets of the bombs, finding means to threaten with them, constantly increasing the numbers of them until we have over 30,000 of them in place each of them greater in explosive power than those used at Hiroshima and Nagasaki."12" We have heard of ten of how horrible it would be if an irresponsible leader, usually envisioned as being from a third world country, should obtain control of nuclear weapons. But it should not be forgotten that it was the United States that used the weapons and accepted the recommendations of Stimson and others that they be used against a "vital war plant employing a large number of workers and closely surrounded by workers' homes."121

And while we are aware of the dangers of the nuclear arms race, our leadership continues to assert the use of nuclear weapons as a first use and first strike weapon, even as we know that at least six nations presently have them. The question which this raises is a double one. We have been told in a Supreme Court case that neither the Constitution nor the United States is a "suicide pact."122 Yet these weapons make clear that states have become entities which hold the mortgage on the lives of the citizenry. Do we have no rights as citizens against this state of affairs? And what are the human and natural rights of a citizenry against a national security system which leads to violence, anxiety and genocide? As Craig Comstock has pointed out, the arms race will lead to our sudden ruin; the brush-fire war policy will lead to a waste of money; and fear of dissident groups, racial minorities, and the unemployed will lead to police repression: "Most serious perhaps, to the degree that we rely on these kinds of violence done in our name, we will be unable to

118. M. SHERWIN, supra note 12 , at 110.

119. Id.

120. Center for Defense Information, America's Nuclear Arsenal, l (Winter 1975). This is a somewhat conservative estimate. In a conversation with the Director of Public Affairs for the Arms Control and Disarmament Agency, Pedro San Juan, the number of nuclear warheads of all sizes in the United States arsenal is, according to him, over 40,000.

121. M. SHERWIN, supra note 12, at 144-5.

122. M. Raskin, Being and Dolvg 36 (1971). 
move toward policies of cooperation (where possible), disengagement (where necessary), or political development toward a more humane society." 123

We may begin to find insights to answer these questions by reviewing the Nuremberg and Asian War Crimes Trials so that we can comprehend proscribed behavior on the part of governments. In the Ninety-fourth Congress, Representative Robert Kastenmeier and thirty-seven colleagues introduced legislation to set up a system of personal accountability of government officials. ${ }^{124}$ It uses the standards that the Americans had applied to the Japanese and Germans after the second world war, including bureaucratic standards of behavior developed prior to the beginning of the cold war. These standards can reach the entire issue of the national security apparatus because they are based not on values which are imperial in nature but on a recognition that governments must be controlled if civilization is not to be lost. This legislation begins to open the debate on national security standards. It could be used as an opening wedge to tame and transform the national security bureaucracy.

The development of scientific and technological wizardry in relation to the ability of a bureaucracy to organize the resources of the society for military and defense purposes has resulted in armaments becoming the measure of state power. But, as the armaments race deepens, so does the moral contradiction to it become more obvious. This moral contradiction is also reflected in the fact that the armaments themselves increase anxiety, distort the value and priority structure within the arming nation, and ultimately cause an interdependent link between military bureaucracies of opposing sides who use each other to rationalize their commitment to arming.

It is not too late to break this dance of death. In this context, three specific and immediate questions are to be considered. (1) If the United States were now to stop any further production of nuclear weapons and missiles, would it be any less secure? (2) Should not American government officials be held to a standard of personal accountability, as outlined in Kastenmeier's proposed bill, ${ }^{125}$ so that aggressive war will not be a part of the national security bureaucrat's kit? (3) Should people in the armed forces be able to unionize for wages, hours, and a code of ethics which would exclude the use of genocidal weapons and participation in aggressive wars? In other words, should soldiers and sailors have the power to limit the mode of weaponry and destruction by abiding by an oath of conduct that eschews such weaponry and acts as a control over unconstitutional wars of aggression?

While such questions must now be opened and debated in society as a

123. N. Sanford \& C. Comstock, Sanctions for Evil 293 (1971).

124. 121 CoNG. Rec. H6396 (daily ed. July 8, 1975) (introduction of H.R. 8388, the Official Accountability Act of 1975, by Representative Robert Kastenmeier).

125. Id. 
whole, it is still necessary to press for disarmament arrangements through the national security bureaucracies as they are presently organized. In 1961, the United States and the Soviet Union agreed to the McCloy-Zorin "eight points" which outlined principles for obtaining universal disarmament. ${ }^{126}$ This memorandum could be used as a basis for reopening the disarmament question. In 1963 the signatories to the partial Test Ban Treaty proclaimed as their principal aim "the speediest possible achievement of an agreement on general and complete disarmament under strict international control in accordance with the objectives of the United Nations which would put an end to the armaments race and eliminate the incentive to the production and testing of all kinds of weapons, including nuclear weapons."12

It remains possible to set the motion for general disarmament in three stages:

As a first stage, the United States must undertake unilateral steps, such as banning future missile production as well as uranium and plutonium production. Outmoded alliance commitments which justify elaborate military forces must be transformed. A process of "agonizing reappraisal" and reconsideration must be instituted in the bureaucracy so that policy decisions for disarmament will not be sabotaged.

This will make possible a second stage which will include the disarmament of troops, nuclear weapons, and missiles from different regions of the world. Thus, for example, the nuclear free zone concept should be reinitiated for the Pacific. The context for discussion on disarmament in the second stage could begin in the United Nations Security Council with the permanent members laying out the basis for determining the questions and concerns of disarmament. Thus in 1977 the United States, for example, should convene a United Nations Security Council meeting with a series of studies about disarmament, including the means of accomplishing and preserving it. These disarmament proposals would be debated in the Council for at least a year during which time an agreed upon position would develop. That position would include these steps: consensus as to what nations should do on their own without inspection; the reduction of missiles and nuclear weapons, unilaterally and through negotiation; development of inspection techniques and collateral forms of inspection; budget examinations as suggested under the Helsinki agreements; and the reduction and abolition of armaments over a period of ten years. Past plans have correctly called for the staged reduction of armaments in which the great powers would reduce their forces first in the context of a worldwide disarmament and arms control plan. Less heavily armed nations would be more likely to follow suit.

In a third stage the success of so-called "confidence building" measures

126. Declaration of Disarmament, Deptr State Bul..., Oct. 16. 1976, at 650.

127. Nuclear Weapons Test Ban, Aug. 5, 1963, 2 U.S.T. 1314, 1316, TI AS No. 5433. 
would cause national leaders to move to the abolition of weapons and armed forces. Such plans should now be exhumed and studied by Congress in the light of current needs and realities. It should be noted that certain new plans have been proposed which bear careful study because they include the actions of non-governmental groups and citizens. For example, the plan for general disarmament put forward by the Nobel Peace Prize winner Sean MacBride outlines actions to be taken by non-governmental groups with transnational and United Nations organizations. ${ }^{128}$

The Department of Defense hopes to increase the defense budget to $\$ 160$ billion per year in the next five years. ${ }^{129}$ It is to be expected that the Soviet defense budget and those of other nations will correspondingly increase. Presently the world is spending $\$ 315$ billion a year on defense. ${ }^{130}$ There is no security or budgetary relief in sight. Our choices are stark and obvious.

\section{Conclusion}

The national security state is the synthesis of state power and capitalism. Its emergence as a political form turned out to be a crucial step in keeping a level of unity within the United States as it attempted to sustain an imperial or hegemonic thrust in the world. But there has been no way for it to transcend its own internal contradictions. It has been grounded on continuous preparation for war, on a passive and receptive society which would automatically accept the judgments of the administrative leadership, on a code of loyalty to authority which would guard people against cultural diversity and ideological impurity, and on a system of economic growth which would mask costs of armaments and empire. It has hoped to hide behind the bonapartist skirts of a president and has sought to hide its own actions from public view. None of these conditions now pertain in the United States. The national security state consensus lasted for approximately fourteen years before it became clear that its specifications had nothing to do with the democratizing process, indeed, that it was authoritarian and criminal in its mode of operations. It was both natural and predictable that the democratizing process would put the national security apparatus on the block.

In an important sense the United States is a Hegelian society in that people are invariably trying to actualize human ideals. They do so out of either a

128. Proposal for a World Disarmament Conference (1975). There is to be a special session of the General Assembly of the United Nations in August 1978 to discuss comprehensive disarmament proposals.

129. Based on $\$ 120$ billion FY 1978 budget - a straight line projection of 9 to 11 per cent which reflects a 4 per cent increase per year in quantum of men and machines for the next 3 years, plus a 6 per cent rate of inflation per year for 3 years. These are very conservative estimates.

130. United Nations Ass'x, Controming the Conventonal Arms Race 4 (1976). 
sense of pain with their current condition, or a sense of surplus which they would like to share with others. The process of this actualization is often humorous, sometimes grotesque and perverted. Nevertheless, the impulse is present. It is a democratic impulse which seeks a social contract in which all members of the society participate. The principle of citizenship assumes that people have individual rights and rights of participation. This process of "leveling," which began with Locke's defense of the bourgeois class so that it would be included in decision making, has found its natural historic result in the cultural, political, and economic struggles which have occurred in the United States over the last fifteen years. That Locke's ideas were meant to be restricted to men of property and wealth no longer matters. What does matter about his view is that governing depends upon the governed. Once it is concluded (and this occurred through monumental struggles of revolution, civil war, and social protest) that there shall be no slavery but rather equality between people of different color, that women are equal to men, that homosexuals have rights and are also equal, that people should have a participatory voice in their place of work, then the society is on a collision course with its state apparatus.

It has been the historic role of liberalism to distill the changes which the militancy of revolt reflects and to replace this militancy with an ordered method of bringing about change. As Chateaubriand said, "[W]e must preserve the political work which is the fruit of the Revolution ... but we must eradicate the Revolution from this work." "131

However, liberalism lost its mediating role and the practitioners of liberalism found themselves as political covers for the national security state. They were coopted and they became the fig leaf for imperialism. Liberals embraced the national security state as the compromise between fascism and socialism within the United States. They worked on means of organizing imperialism and of using the Keynesian principle of economic growth and defense spending as a central mechanism of avoiding class conflict. But this choice has given rise to new perplexities. Liberals have not been able to hold back the dual state, internalize the cultural revolution of the $1960 \mathrm{~s}$ in their thought and action, or criticize in any fundamental sense the corporate oligopoly system. Thus, the political question is whether liberals have any sort of role to play as mediators in a society whose ideological compass is broken. It would seem that they have none unless they renounce the national security apparatus and develop a full employment economy which is not dependent on the whims of corporations or the defense department. They need also realize that the democratizing process must include economic democracy and the means of holding in common what is basic to the well-being of the society. These are

131. G. Novack, supra note 4. at 120. 
matters which must be debated locally, in schools, factories, churches, and neighborhood bars.

The society is at a turning point. And in this regard so is the legal profession. Either we will surrender representative democracy, embracing instead different forms of corporate fascism and bureaucratic control (military, police, and social) which cannot be halted through citizen action and democratic processes, or we (including the legal profession) will begin the difficult task of dismantling the national security apparatus. It does not seem likely to me that those who struggled in the sixties to develop a new meaning of democracy will settle for bureaucratic or corporate fascism. And those who are neutral on the question will be less likely to acquiesce in fascist or bonapartist deformations once it is clear that they are inefficient, and that they provide only insecurity, unemployment, imperial wars, a deepening arms race, and a process of repressive exclusion which reduces politics to an empty game. 